\title{
Control of plant-parasitic nematodes using cover crops in table grape cultivation in Chile
}

\author{
Cecilia Baginsky, Américo Contreras, José Ignacio Covarrubias, Oscar \\ Seguel, and Erwin Aballay \\ Facultad de Ciencias Agronómicas, Universidad de Chile. Casilla 1004, Santiago, Chile.
}

\begin{abstract}
C. Baginsky, A. Contreras, J.I. Covarrubias, O. Seguel, and E. Aballay. 2013. Control of plant-parasitic nematodes using cover crops in table grape cultivation in Chile Cien. Inv. Agr. 40(3): 547-557. A study to evaluate the effect of a three-year rotation with cover crops for the management of plant-parasitic nematodes (PPNs) was performed in two vineyards producing table grapes (Vitis vinifera L.) in a semiarid region in the north of Chile. In the first vineyard, located in Copiapó valley (trial I), the crops used in the rotations or monoculture were fava bean (Vicia faba) cv. Aguadulce, rape (Brassica napus var. napus) cv L-456, forage turnip (B. rapa var. rapa) cv. Barkant, barley (Hordeum vulgare) cv. Aurora, oat (Avena sativa) cv. Urano-INIA, and mustard greens (Brassica juncea). At the second vineyard employed in the study, located in Huasco valley (trial II), the same crops and varieties were used in a rotation system with the incorporation of crop/goat manure mixtures or manure only at a rate of $10 \mathrm{Mg}$ $\mathrm{ha}^{-1}$. In both studies, two control treatments were included: a nontreated control and a chemical control in which ethoprop was applied at a rate of $7 \mathrm{~kg} \mathrm{ha}^{-1}$. The results from trial I indicated no significant differences between the cover crop rotation treatments and controls for Xiphinema index and for the other PPNs populations. In trial II, treatments 4 (manure) and 5 (manure and crop rotation) showed significantly lower values compared to treatment 2 (chemical control), with the highest $X$. index levels, but no differences from the control. No differences were detected for the other PPNs.
\end{abstract}

Key words: Vitis vinifera, crop protection, nematicidal plants, botanical nematicides.

\section{Introduction}

Grapevine (Vitis vinifera L.) is an economically important crop in Chile, with a cultivated area of approximately 189,000 ha (Guerrero and Gutiérrez, 2012). However, many soil-borne pathogens

Received June 26, 2013. Accepted October 28, 2013. Corresponding author: cbaginsky@gmail.com and pests can damage or completely destroy the new roots that are initiated in spring and after the fruit harvest in late summer. Several genera and species of plant-parasitic nematodes (PPNs) have been reported to cause economic damage to grapevines and are commonly found in vineyards; the most frequently found species are Xiphinema index, Meloidogyne ethiopica, Mesocriconema xenoplax, and Tylenchulus semipenetrans (Aballay 
et al., 2009). The presence of PPNs continues to be one of the most important problems affecting the root system of grapevines, with damage normally being reflected in lower production and, in some cases, total crop loss. Several studies have estimated that PPNs cause global losses of US\$ 78 billion in agriculture, indicating an annual yield loss of $12.5 \%$ in table grapes (Smiley, 2005; Sasser and Freckman, 1987). The damage caused by nematodes varies depending on many factors, such as soil type, cultivar, climate, and crop management (Ferris and McKenry, 1974).

Multiples classical methods and strategies are used for the management of PPNs. Currently, the control of PPNs in Chile is based on the use of chemical nematicides, mainly carbamates and organophosphates, applied once or twice per year. Despite these treatments, the nematode population remains almost unchanged (Valenzuela and Aballay, 1996) due to the low residual effect of nematicides, the loss of efficacy with frequent irrigation, and the use of organic amendments, among other soil and application factors. Vineyards affected by PPNs eventually exhibit destroyed roots due to the direct damage by PPNs and/or secondary damage by several fungi associated with the roots systems, resulting in the necessary replacement of the plants before they are 15 years old, i.e., achieving less than $50 \%$ of their potential productive life (Pinkerton et al., 1999; Montealegre et al., 2009). However, even after the affected plants are removed, the soil remains infested for many years due to the long-term persistence of PPNs in the deep soil layers (McKenry, 1999).

Soil fumigants and different rootstocks are alternative approaches under replanting conditions, though these strategies are not extensively used by most growers because the chemicals are fairly expensive and because rootstocks are typically not tolerant to all nematodes, e.g., X. index or M. xenoplax (Sellés et al., 2012, Aballay et al., 2009).
Although the control of PPNs in Chile is mainly based on the use of agrochemicals, crop rotations and their stubble management have been proposed as alternatives to chemical control (Aballay et al., 2004). The use of antagonistic plants has also been evaluated and employed in some vineyards. The modes of action of antagonistic plants have been reported to be the presence of nematotoxic root exudates that can affect PPNs (Bello, 1998) or the stimulation of root growth (Birch et al., 1993). Several plant species have been evaluated for PPN management, including plants belonging the genera Tagetes, Cosmos, Gaillardia, Zinnia (Tsay et al., 2004), and such Brassicaceae as Brassica napus L., Sinapis alba L., and Raphanus sativus L. (Halbrendt, 1996). The nematicidal effect of 77 plants has been assessed in in vitro, in potted plants, and in field experiments in Chile, and it was determined that most were effective against $X$. index and X. americanum s.l. (Aballay et al., 2001, 2004; Insunza et al., 2000, 2001). The effect of these cover crops depends on the species of plant selected, soil type, nematodes present, and crop management. Nevertheless, the improper selection of a plant may result in adverse effects to the main crop (McLeod, 1994).

Therefore, the aim of this study was to assess the effect of cover crops or intercrops on the nematode populations in two vineyards during three years in a semiarid region in the north of Chile.

\section{Materials and methods}

Location and edaphoclimatic characteristics of the vineyards

Two established 8-year-old, own-rooted vineyards located in the north of Chile, the Copiapo vineyard of cv. Flame Seedless ( $27^{\circ} 36^{\prime} \mathrm{S}, 70^{\circ} 19^{\prime} \mathrm{W}$ ) in a $1.5 \times 3.0-\mathrm{m}$ distribution and the Huasco vineyard of cv. Red Globe ( $28^{\circ} 37^{\prime}$ S, $70^{\circ} 42^{\prime}$ W), Atacama Region, were selected (Figure 1). In the Copiapó vineyard, the soil is of the Amolanas Series (Typic 
Haplocambid), consisting on an alluvial terrace, with moderately deep, well-drained soil (CIREN, 2007). The soil texture is mainly sandy loam, with coarse textures in the deeper layers. The Ap horizon is strongly saline, and there is a moderate effervescence with $\mathrm{HCl}$ along the soil profile. The climatic conditions (BWI; Juliá et al., 2008) are characterized by low winter precipitation $(<$ $20 \mathrm{~mm}$ annual), with daily average temperatures fluctuating between $25^{\circ} \mathrm{C}$ in summer and $5{ }^{\circ} \mathrm{C}$ in winter. In the Huasco vineyard, the soils are of the Cavancha Series (Xerollic Haplargids), are located in an alluvial remnant terrace with a flat topography, and are well drained. The texture is a loamy soil at the upper layers and a clayey loamy texture below $70 \mathrm{~cm}$. The Ap horizon is not saline and does not react with $\mathrm{HCl}$. The area is characterized by high temperatures in January, with an average of 26.5 ${ }^{\circ} \mathrm{C}$ and minimum of $5.7^{\circ} \mathrm{C}$ in July without frosts, and precipitation of $25 \mathrm{~mm}$ (Osorio et al., 1995).

\section{Treatments in the Copiapó vineyard}

The trial was established in an eight-year-old grape cv. Flame Seedless vineyard using an overhead trellised system in a frame of $1.5 \mathrm{~m}$ $\times 3.0 \mathrm{~m}$. Thirty-five plots were established and grouped into five completely randomized blocks with seven treatments (Table 1) based on the use of different annual crops in rotation (T3, T4, T7) or monoculture systems (T5, T6). Additionally, a chemical control treatment (ethoprop $7 \mathrm{~kg} \mathrm{ha}^{-1}$; T2) and a no treatment control were included.

The crops used in the rotations were as follows: fava bean (Vicia faba) cv. Aguadulce; rape (Brassica napus var. napus) cv. L-456; forage turnip (Brassica rapa var. rapa) cv. Barkant; barley (Hordeum vulgare) cv. Aurora; oat (Avena sativa) cv. Urano-INIA; and mustard greens (Brassica juncea). These annual crops were sown by hand on the ridge ( $1 \mathrm{~m}$ wide) of the vine row during the first week of January of each year (mid summer). Fava bean at a rate of $80 \mathrm{~kg} \mathrm{ha}^{-1}$ was established in seven rows spaced $15 \mathrm{~cm}$ apart along the vine row and $15 \mathrm{~cm}$ within the row and inoculated with Rhizobium leguminosarum sv. viciae at a rate of $50 \mathrm{~g}$ of inoculants per $100 \mathrm{~kg}$ of seed. Forage turnip, oat, and barley were sown in a continuous stream in nine rows spaced $15 \mathrm{~cm}$ apart in the vine row at rates of 15,95 , and $70 \mathrm{~kg}$

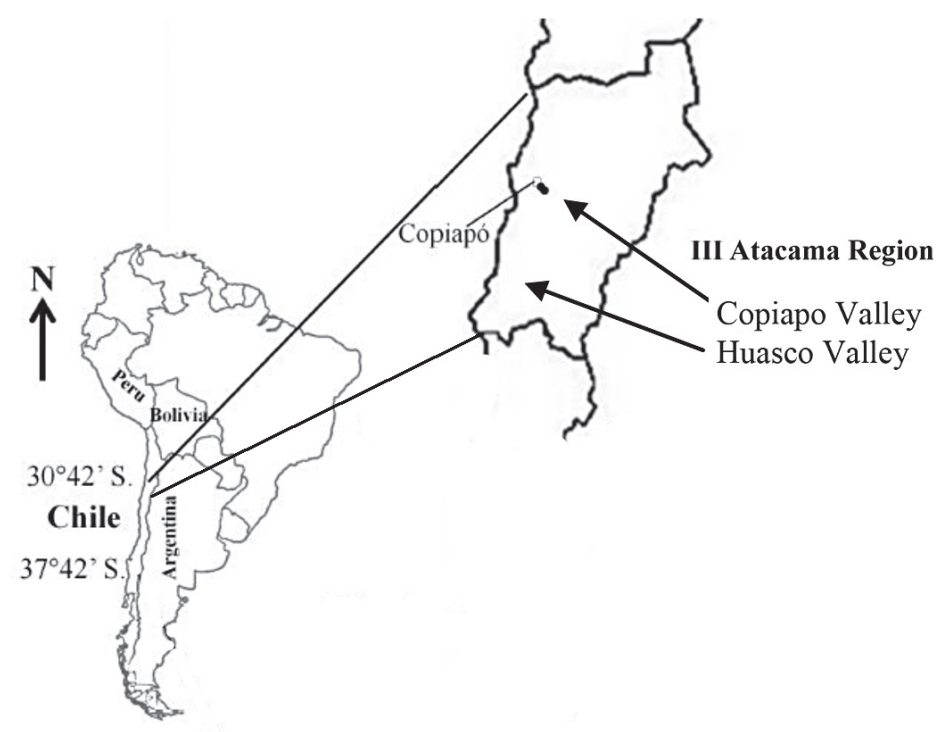

Figure 1. Map of northern Chile. Trial I was conducted in a vineyard located in Copiapo valley $\left(27^{\circ}\right.$ $\left.36^{\prime} \mathrm{S}, 70^{\circ} 19^{\prime} \mathrm{W}\right)$, and trial II was conducted in a vineyard located in Huasco valley $\left(28^{\circ} 37^{\prime} \mathrm{S}, 70^{\circ}\right.$ 42 ' W). Both valleys are located in the Atacama region, Chile. 
$\mathrm{ha}^{-1}$, respectively. The plants were manually cut and incorporated into the first $20 \mathrm{~cm}$ of the soil just before grapevine bud brake in July of each year. Samples of the cover crops were collected for biomass determinations (data not shown).

A chemical control was applied on September of each year by adding the product directly to the root zone at four points $50 \mathrm{~cm}$ from the vine axis and at a depth of $30 \mathrm{~cm}$ using an injector. The vineyard had a drip irrigation system with a double line and drippers of $4 \mathrm{~L} \mathrm{~h}^{-1}$ separated by $1 \mathrm{~m}$ along the line.

\section{Treatments in the Huasco vineyard}

A monocrop system and the incorporation of a mixture of crops and manure were included in this trial. The trial was established in an eight-year-old cv. Red Globe vineyard using an overhead trellised system in a frame of $3.5 \mathrm{~m} \times 3.5 \mathrm{~m}$. In the year prior to establishing this trial, an amendment with manure was performed by incorporating goat manure $(68.7 \%$ OM, pH 7.3, 1.7\% total N, $355 \mathrm{mg}$ $\mathrm{kg}^{-1}$ available $\mathrm{P}$, and available $\mathrm{K}, \mathrm{Ca}$, and $\mathrm{Mg}$ at $36.3,18.7$ and $22.5 \mathrm{cmol} \mathrm{kg}^{-1}$, respectively) at a rate of $10 \mathrm{Mg} \mathrm{ha}^{-1}$ to the entire vineyard.

Twenty-five plots were identified and grouped into five completely randomized blocks with four treatments (Table 1): control (T1); chemical nematicide control (ethoprop $7 \mathrm{k} \mathrm{ha}^{-1}$ ) (T2); crop rotation (fava bean-mustard greens-oat) (T3); and crop rotation (fava bean-barley-mustard greens) established over manure (T4). The cultivars of fava bean, barley, mustard greens, and oat were the same as those used for Trial I, and the managements were essentially the same. These annual crops were sown by hand on and between the vines rows (T3) or on the manure (T5) during autumn (March) of each year. The seeding procedure was similar to that used in Trial I, but the T3 the crops were established in a total of 18 rows at $20-\mathrm{cm}$ spacing. In this case, the seeding rate of fava bean, mustard greens, and oat was 200,35 , and $250 \mathrm{~kg}$

Table 1. Treatments established in the Copiapó and Huasco vineyards during three consecutive seasons using cover crops.

\begin{tabular}{|c|c|c|c|c|c|}
\hline \multirow[b]{2}{*}{ Vineyard } & \multirow[b]{2}{*}{ Treatment } & \multirow[b]{2}{*}{ Description } & \multicolumn{3}{|c|}{ Season } \\
\hline & & & One & Two & Three \\
\hline \multirow[t]{7}{*}{ Copiapó } & $\mathrm{T} 1$ & Untreated & * & $*$ & * \\
\hline & $\mathrm{T} 2$ & Chemical nematicide & Ethoprop & Ethoprop & Ethoprop \\
\hline & $\mathrm{T} 3$ & Rotation 1 & Fava bean & Mustard greens & Oat \\
\hline & $\mathrm{T} 4$ & Rotation 2 & Fava bean & Barley & Rape \\
\hline & T5 & Monoculture 1 & Rape & Rape & Rape \\
\hline & T6 & Monoculture 2 & Forage turnip & Forage turnip & Forage turnip \\
\hline & $\mathrm{T} 7$ & Rotation 3 & Rape & Fava bean & Mustard greens \\
\hline \multirow[t]{5}{*}{ Huasco } & $\mathrm{T} 1$ & Untreated & $*$ & $*$ & $*$ \\
\hline & $\mathrm{T} 2$ & Chemical nematicide & Ethoprop & Ethoprop & Ethoprop \\
\hline & $\mathrm{T} 3$ & Rotation & Fava bean & Mustard greens & Oat \\
\hline & $\mathrm{T} 4$ & Manure & Goat manure & Goat manure & Goat manure \\
\hline & $\mathrm{T} 5$ & Manure and rotation & $\begin{array}{c}\text { Goat manure } \\
\text { bean }\end{array}$ & $\begin{array}{c}\text { Goat manure }+ \\
\text { Barley }\end{array}$ & Goat manure + Mustard greens \\
\hline
\end{tabular}

*No chemical control, without crop rotation and manure. 
$\mathrm{ha}^{-1}$, respectively. In T5, manure was applied on the vine row at a rate of $12.5 \mathrm{Mg} \mathrm{ha}^{-1}$ year $^{-1}$, and the crops were sown over this amendment. Fava bean was planted in four rows spaced at $20 \mathrm{~cm}$ apart, with a plant spacing of $12 \mathrm{~cm}$ at a rate of 22 $\mathrm{kg} \mathrm{ha}^{-1}$, and barley and mustard were planted in a continuous stream at rates of 20 and $4 \mathrm{~kg} \mathrm{ha}^{-1}$, respectively. The vineyard was irrigated through a double irrigation line system with drippers of 4 $\mathrm{L} \mathrm{h}^{-1}$ separated by $1 \mathrm{~m}$ along the line. The plants were manually cut and incorporated into the first $20 \mathrm{~cm}$ of the soil just before grapevine flowering in August of each year. Samples of the cover corps were collected for biomass determinations (data not shown). The chemical nematicide ethoprop was applied during the three growing seasons in the month of September (spring), the normal time for the application of these chemicals, following the same method stated above.

Prior to seeding the cover crops, an extra irrigation was applied in both trials but was based on the needs of vine during the season the management (fertilization and irrigation), according to the normal program used by the farmer. Weeds were manually controlled. The cover crops were allowed to develop until the application of a sprouting controller (hydrogen cyanamide) in July-August at which time the plants were manually chopped, distributed on the inter-row, and irrigated to support decomposition and the penetration of exudates into the soil.

\section{Assessments}

Soil and root samples were collected prior to the establishment of the trials. Using a shovel, samples were collected to a depth of 25-35 cm within rows where most of the feeder roots are present. Approximately 10 subsamples were collected at random to produce a 1-L sample. The subsamples were mixed, placed in plastic bags, and stored at $8{ }^{\circ} \mathrm{C}$ until they were processed approximately two weeks later.
Nematodes were extracted from a $250-\mathrm{cm}^{3}$ soil volume by decanting/sieving through nested 710-, $250-, 150-$, and $45-\mu \mathrm{m}$ sieves (Southey, 1986). The final suspension was decanted onto filter paper and placed on a Baermann funnel for $48 \mathrm{~h}$. To obtain an optimal recovery of adults and of the fourth juvenile stage of the species of Xiphinema, soil samples suspended in water were passed through 750 - and $250-\mu \mathrm{m}$ sieves only and then placed on a nylon sieve of $90-\mu \mathrm{m}$ on a Baermann funnel for $24 \mathrm{~h}$ (Brown and Boag, 1988). Counting and identification were performed using a stereoscopic microscope (Zeizz, Stemi 2000-C, Göttingen, Germany).

\section{Experimental design and statistical analyses}

In the first trial (Copiapó vineyard), the experimental unit was a plot of $7.5 \mathrm{~m}$ long $\times 1.5 \mathrm{~m}$ wide containing 4 vines with their respective ridge (10 $\mathrm{cm}$ height). Nematode sampling was performed for the two central plants in each plot. In the second trial (Huasco vineyard), the experimental unit was a plot of $14 \mathrm{~m}$ long $\times 7 \mathrm{~m}$ wide containing 8 vines distributed in two rows of four plants per row. Considering a borderline effect, only the two central plants per row and the respective soil were included in the evaluations.

To evaluate the effect of the different treatments, the reproductive index $(\mathrm{R})$ was calculated, which relates the final population (Pf) with the initial population (Pi) (Oostenbrink, 1966); the final population corresponds to that obtained at the end of the third season of the study. Prior to calculating $\mathrm{R}$ and performing an analysis of variance (ANOVA), the nematode population density data were transformed as $\log (\mathrm{x}+1)$ for normalization, as suggested for nematode counts that are skewed, with a normally negative binomial distribution (Noe, 1985). When significance at $\mathrm{P} \leq 0.05$ was detected, the treatment means were compared according to Tukey's multiple range test. 


\section{Results}

In the Copiapó vineyard, $X$. index was the major PPN founded, followed by Meloidogyne spp., $M$. xenoplax, Paratylenchus sp., Pratylenchus thornei, Hemicycliophora sp., and T. semipenetrans. The density of nematodes present in $250 \mathrm{~cm}^{3}$ of soil for each taxon was as follows: $X$. index, 310; Meloidogyne ethiopica, 55; Mesocriconema xenoplax, 110; Paratylenchus sp., 21; and others in lower numbers and only occasionally detected. The effect of the treatments was assessed independently for $X$. index and the other PPNs present.

The effect of cover crops on the densities of $X$. index populations was not different between the chemical treatment and untreated control, though a clear tendency toward $\mathrm{R}$ values $<1$ was observed with some of the cover crops (Figure 2), mainly treatments 3 (rotation 1, fava bean, mustard greens, oat), 5 (monoculture of rape), and 6 (monoculture of forage turnip).

The effect of the treatments on the other PPNs present in trial I (Figure 2) was similar to that found for $X$. index, with no significant differ- ences among the treatments, despite treatments 2 (chemical control), 3 (rotation 1, fava bean, mustard greens, oat), 4 (rotation 2, fava bean, barley, rape), 6 (monoculture of forage turnip), and 7 (rotation 3, rape, fava bean, mustard greens) exhibiting a lower $\mathrm{R}$ than the control treatment.

In the Huasco vineyard, the nematode densities detected prior to the establishment of the treatments was also dominated by $X$. index (460 nematodes $/ 250 \mathrm{~cm}^{3}$ soil), followed by $M$. xenoplax (70 nematodes $/ 250 \mathrm{~cm}^{3}$ soil), P. thornei (35 nematodes $/ 250 \mathrm{~cm}^{3}$ soil), and $M$. ethiopica (21 nematodes $/ 250 \mathrm{~cm}^{3}$ soil). When the treatment effects were assessed with regard to the variation of $X$. index populations (Figure 3 ), the $\mathrm{R}$ of treatments 4 (manure) and 5 (manure and crop rotation) showed significantly lower values compared to treatment 2 (chemical control). This result showed the null effect of the nematicide compared to the alternatives, with both presenting values lower than 1 . Both treatments 4 and 5 included manure, which was applied during the three years of the study. No differences were detected when these treatments were compared to the control (Figure 3).

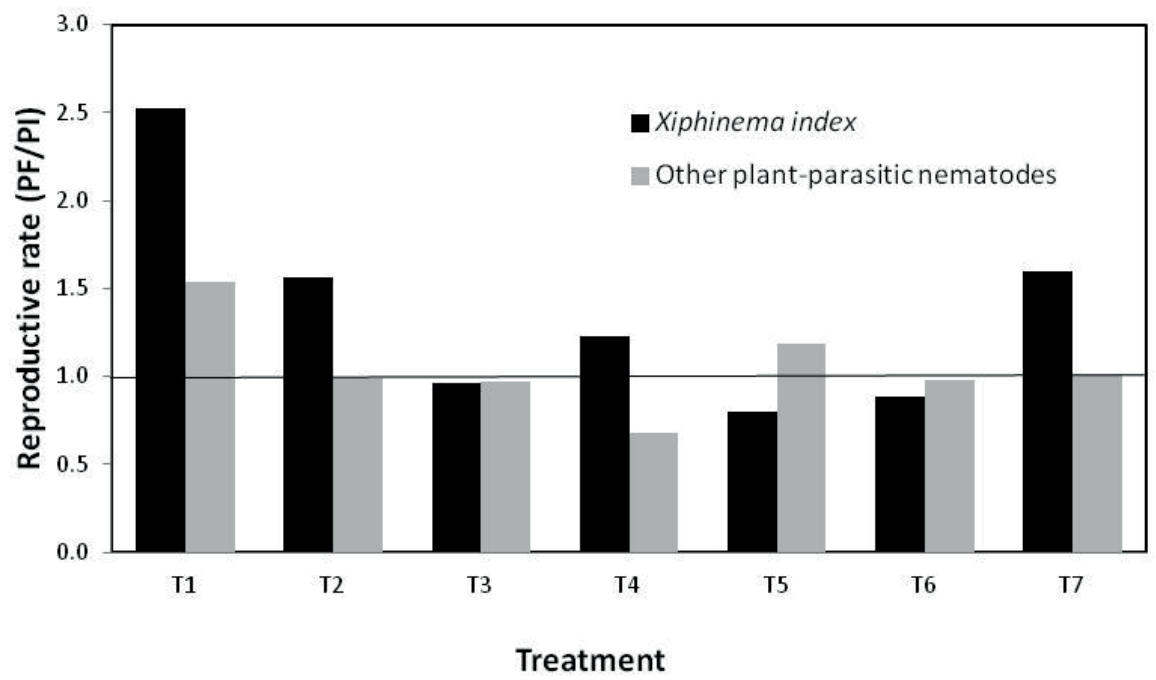

Figure 2. Reproductive index of Xiphinema index and other plant-parasitic nematodes in the Copiapó vineyard. T1, control; T2, chemical control (ethoprop); T3, rotation 1 (fava bean, mustard greens, Oat); T4, rotation 2 (fava bean, barley, rape); T5, monoculture 1 (rape); T6, monoculture 2 (forage turnip); T7, rotation 3 (rape, fava bean, barley, mustard greens). No significant differences were detected between the treatments according to an ANOVA test $(\mathrm{P} \leq 0.05)$ 
The effect of the treatments on the other PPNs present in this vineyard showed that the populations remained at similar densities, without significant differences in R (Figure 3). The control exhibited an $\mathrm{R}$ value close to 1 , revealing no variation in the nematode population over time. However, the chemical control had an $\mathrm{R}$ value greater than 1 , similar to that observed with $X$. index. Treatments 4 and 5 also showed a tendency to reduce the PPN population densities.

\section{Discussion}

The results show that the incorporation of organic matter through the use of cover crops during a period of three years was not able to produce a significant decrease in PPNs under the conditions of these trials. Xiphinema index is a nematode that presents a wide distribution in the vineyards from this region; for many years, chemical nematicides have been the control method employed yet can be an environmental contaminant, and few effects have been achieved (Valenzuela and Aballay, 1996). The use of some nematicidal plants was able to reduce $X$. index population densities in potted plant experiments (Aballay et al., 2004), but the size of the roots system in a productive vineyard would indicate that the infested area is much larger and that the impact of cover crops may not be sufficient as a control measure. Indeed, most of the studies using cover crops have been performed in combination with annual crops, with a much smaller root system.

The lack of control is not influenced by the crop used, as most of these nematodes are not able to reproduce on the crops, and only leguminous plants can serve as a host for M. ethiopica. Some studies under field conditions have reported promising results with certain plants, such as Vicia villosa and Tagetes minuta, grown between two successive vine crops, without incorporation into the soil, and without vines (Villate et al., 2012). It is possible that the presence of the vine roots in our study is a permanent stimulus to maintain the growth of nematodes and that the effect of crops is not observed with the same intensity, as also occurred with the action of different cover crops on $X$. americanum s.l. in wine grape vineyards (Aballay et al., 2001). In the Copiapó vineyard, the monocrops rape seed and forage turnip caused a reduction in the $X$. index populations, but it was not different from the treatment chemical

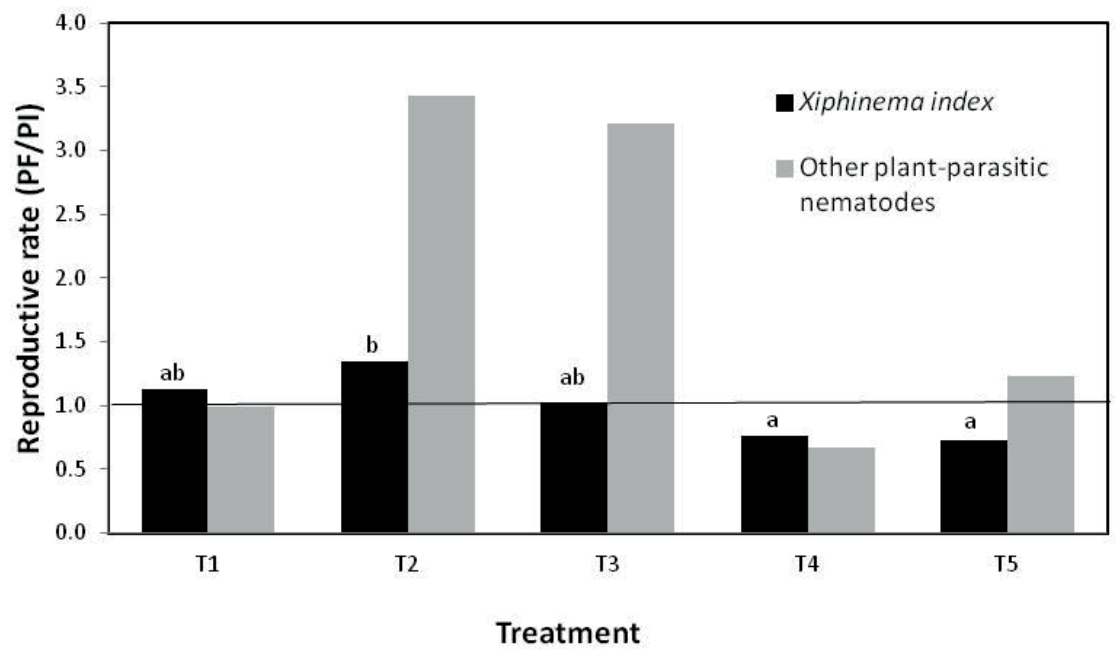

Figure 3. Reproductive index of Xiphinema index and other plant-parasitic nematodes in the Huasco vineyard. T1, untreated; T2, nematicide; T3, rotation F-M-O (fava bean, mustard greens, oat); T4, manure; $\mathrm{T} 5$, manure and rotation F-M-O. The different letters indicate significant differences according to Tukey's test $(\mathrm{P} \leq 0.05)$. 
nematicide. In contrast, some monocrops can increase PPNs populations (Rahman et al., 2007). The same trend was observed with the use of goat manure for three years and the mixture of goat manure with fava bean, barley, and mustard green rotations in the Huasco vineyard. Indeed, the use of manure has proven be an efficient alternative for controlling different PPNs in several crops (Rodriguez-Kábana et al., 1987) and in grape vines (Rivera and Aballay, 2008). In this study, the observed differences may be due to the application rate, which has not been determined for different manures and conditions of grapevine growth. In our study, $10 \mathrm{Mg} \mathrm{ha}^{-1}$ was applied, which may be good for stimulating root growth. However, to have some incidence o nematode control it has been suggested manure amounts over $110 \mathrm{Mg} \mathrm{ha}^{-1}$ under complete under broadcast basis, or 30-40 $\mathrm{Mg}$ only to the equivalent surface planted (Mian and Rodriguez-Kábana, 2001).

The use of chemical nematicides was not able to decrease the nematode populations, showing that this approach is not different from the use of alternative management practices. In the Huasco vineyard, the reduced activity of ethoprop may have been influenced by the previous use of manure in this field, considering that organophosphate chemicals tend to be fixed in organic matter, thereby losing their efficacy (Bunt, 1987).

The use of manure and cover crops with manure tend to decrease nematodes, with recommendations of the use of crop rotations and crop residue retention for better results (Govaerts et al., 2007). The effect of the nutrients provided by the manure could support a better sanitary condition of the vines, decreasing the PPNs populations, as was observed by Rahman et al. (2007) for treatments with $\mathrm{N}$ fertilization in a long-term field experiment. In our study, due to the pest pressure and soil and weather conditions, there may not have been enough time to improve root growth and decrease PPNs activity.

Previous works with some of these crops have shown that barley is efficient in decreasing populations of Meloidogyne hapla (Bowman et al., 2000). In other studies performed by Scholte and Lootsma (1998) and Bauer et al. (2010), it was determined that the incorporation of oat plants prior to blooming decreased the population densities of M. xenoplax associated with potato crops and peaches, respectively. However, including oat was the least effective treatment in our study.

In previous studies with $V$. faba as a cover crop, it was demonstrated that the presence of Nacobbus aberrans and Globodera spp. in potato crops was decreased between $30 \%$ and $42 \%$ (Iriarte et al., 1998; Pacajes et al., 2002) after incorporation. The plants from this family may have some effect on nematodes due to their low $\mathrm{C} / \mathrm{N}$ ratio, which favors the production of ammonia when the crop residues are incorporated (Mian and Rodriguez-Kábana, 2001), particularly under alkaline conditions, as in both of our study areas, with $\mathrm{pH}$ values between 7.3 and 8 . In addition, some metabolites with pesticide action are produced, including lectins, rotenone, tephrosin, and deguelin (Bowman et al., 2000).

In conclusion, the results of the present study indicate that, under high pressure of PPNs in perennial crops, the use of the cover crops assessed here is not able to reduce the nematode populations and that the possibility of using manure plus crops must be assessed under increasing amounts of manure. Additionally, at least under the soil and weather conditions of our study, chemical control is not an effective alternative to consistently suppress the high nematode populations observed. 


\section{Resumen}

C. Baginsky, A. Contreras, J.I. Covarrubias, O. Seguel y E. Aballay. 2013. Control de nemátodos fitoparásitos mediante el uso de cultivos de cobertera en parronales de uva de mesa en Chile. Cien. Inv. Agr. 40(3): 547-557. Se realizó un estudio destinado a evaluar el efecto de cultivos de cobertura en rotación durante tres años, sobre el control de nematodos fitoparásitos en dos plantaciones de uva de mesa en una región semiárida del norte de Chile. La primera plantación correspondió a un parronal en Copiapó (ensayo I), donde los cultivos utilizados en rotación o en monocultivo fueron haba (Vicia faba) cv. Aguadulce; raps (Brassica napus var. napus) cv L-456; rábano forrajero (B. rapa var. rapa) cv. Barkant; cebada (Hordeum vulgare) cv. Aurora; avena (Avena sativa) cv. Urano-INIA y mostacilla (Brassica juncea). El segundo parronal utilizado para el estudio está ubicado en la localidad de Huasco (ensayo II), donde se utilizaron los mismos cultivos y variedades, en un sistema de rotación, incorporándose además una mezcla de cultivos sembrados sobre guano de cabra y guano de cabra solo, en dosis de $10 \mathrm{Mg} \mathrm{ha}^{-1}$. En ambos estudios se incluyó un control absoluto y un control químico, ethoprop, en una dosis de $7 \mathrm{~kg} \mathrm{ha}^{-1}$. Bajo las condiciones de este estudio, los resultados indican que en el ensayo I, no hubo diferencias significativas en los tratamientos basados en los cultivos de cobertura en rotación y el control de poblaciones de Xiphinema index así como en el resto de los fitoparásitos. En el ensayo II, solo se observan diferencias entre los tratamientos en base solo a guano y guano y rotaciones con el tratamiento químico, siendo este último el menos efectivo de todos los tratamientos. En el resto de los fitoparásitos, no hay diferencias después de tres años de evaluaciones.

Palabras clave: Nematicidas botánicos, plantas nematicidas, protección de cultivos, Vitis vinifera.

\section{References}

Aballay, E., P. Persson, and A. Martensson. 2009. Plant-parasitic nematodes in Chilean vineyards. Nematrópica 39:85-97.

Aballay, E., R. Sepúlveda, and V. Insunza. 2004. Evaluation of five nematode-antagonistic plants used as green manure to control Xiphinema index Thorne et Allen on Vitis vinifera L. Nematropica 34:45-51.

Aballay, E., and V. Insunza. 2002. Evaluación de algunos cultivos en cobertera sobre el control de Xiphinema index en vid de mesa, cultivar Thompson Seedless en la zona central de Chile. Agricultura Técnica 62:357-365.

Aballay, E., P. Flores, and V. Insunza. 2001. Efecto nematicida de ocho especies vegetales sobre $X i$ phinema americanum sensu lato, en Vitis vinifera 1. Var. Cabernet Sauvignon en Chile. Nematropica 31:95-102.
Akhtar, M., and I. Mahmood 1996. Organic soil amendments in relation to nematode management with particular reference to India. Integrated Pest Management Reviews 1:201-215.

Bauer, C., F. Carpena, J. Casagrande, and E. Radmann. 2010. Avaliação do potencial de coberturas verdes e de sistemas de rotações de cultura na supressão do nematoide anelado (Mesocriconema xenoplax) em pré-plantio ao pessegueiro. Revista Brasileira da Fruticultura, Jaboticabal SP 32:74-81.

Bello, A. 1998. Biofumigation and integrated pest management. In: A. Bello, J.A. González, M. Arias, and R. Rodríguez-Kábana (eds.). Alternatives to Methyl Bromide for the Southern European Countries. PhytomaEspaña, DG XI EU, CSIC, Valencia, Spain. p. 99-126.

Birch, A., W. Robertson, and L. Fellows. 1993. Plants products to control plant parasitic nematodes. Pesticide Science 39:141-145. 
Bowman, G., C. Shirley, and C. Cramer. 2000. Benefits of cover crops. In: Managing cover crops profitably. Second Edition. CMR Editorial. United Stated. 201 pp.

Brown, D.J., and B. Boag. 1988. An examination of methods used to extract virus-vector nematodes (Nematoda: Longidoridae and Trichodoridae) from soil samples. Nematologia Mediterranea 16:93-99.

Brown, P. and M. Morra. 1997. Control of soil-borne plant pests using glucosinlate-containing plants. Advance in Agronomy 61:167-231.

Bunt, J.A. 1987. Mode of action of nematicides. In: Veech, J.A., and Dickson, D. (eds.). Vistas on Nematology: A Commemoration of the Twenty-fifth Anniversary of the Society of Nematologists. p. 461-468. Maryland: Society of Nematologists.

CIREN. Centro de Información de Recursos Naturales. 2007. Estudio Agrológico Valle de Copiapó y Valle del Huasco. Región de Atacama, Chile. Publicación $\mathrm{N}^{\circ} 135.145 \mathrm{pp}$.

Ferris, H., and M.V. McKenry. 1974. Seasonal fluctuations in the spatial distribution of nematode populations in the spatial distribution in a California vineyard. Journal of Nematology 6:203-210.

Gardiner, J.B., M. Morra, C. Eberlein, P. Brown, and V. Borek. 1999. Allelochemicals released in soil following incorporation of rapeseed (Brassica napus) green manures. Journal of Agricultural and Food Chemistry 47:3837-3842.

Govaerts, B., M. Fuentes, M. Mezzalama, J. Nicol, J. Deckers, J. Etchevers, B. Figueroa-Sandoval, and K. Sayre. 2007. Infiltration, soil moisture, root rot and nematode population after 12 years of different tillage, residue and crop rotation managements. Soil \& Tillage Research 94: 209219.

Guerrero, A., and A. Gutiérrez. 2012. Efectos de la apertura comercial chilena en la superficie cultivada. Oficina de Estudios y Políticas Agrarias (ODEPA). Santiago, Chile. 3 pp.

Halbrendt, J. 1995. Dagger nematode control on replant sites with selected covercrops and green manure treatments. Pennsylvania Fruit News 75:46-48.
Halbrendt, J. 1996. Allelopathy in the management of plant parasitic nematodes. Journal of Nematology 28:8-14.

Insunza, V., E. Aballay, D. Contreras, and J. Macaya. 2000. Acción nematicida in vitro de extractos de varias plantas en Xiphinema index y X. americanum sensu lato. p. 38. Abstracts of XXXII Annual Meeting of ONTA (Organization of Nematologists of Tropical America). Auburn, Alabama, USA.

Insunza,V., E. Aballay, and J. Macaya. 2001. Nematicidal activity of aqueous plant extracts on Xiphinema index. Nematología Mediterranea. 29:35-40.

Iriarte, L., J. Franco, and N. Ortuño. 1998. Efecto de abonos orgánicos sobre las poblaciones de nematodos y la producción de la papa. Revista Latinoamericana de la Papa 11:149-163.

Juliá, C., S. Montecinos, and A. Maldonado. 2008. Características Climáticas de la Región de Atacama. In: F. A. Squeo, G. Arancio, J. R. Gutiérrez (eds.). Libro Rojo de la Flora Nativa y de los Sitios Prioritarios para su Conservación: Región de Atacama. Ediciones Universitarias de La Serena. La Serena, Chile. p: 25-42.

Kirkegaard, J., and M. Sarwar. 1998. Biofumigation potential of brassicas: I. variation in glucosinolate profiles of diverse field-grown brassicas. Plant and Soil 201:71-89.

McKenry, M. 1999. The Replant Problem and its Management. Fresno, Catalina Publisher, California, United States. 109 pp.

McLeod, R. 1994. Covercrops and inter-row nematode infestation in vineyards. The Australian Grape Grower \& Vinemaker 367:45-48.

Mian, I.H. and R. Rodriguez-Kábana. 2001. Soil amendments with soil cakes and Chicken litter for control of Meloidogyne arenaria. Nematropica 12: 205-220.

Montealegre, J., E. Aballay, S. Sánchez, L. Rivera, N. Fiore, and A. Pino. 2009. Hongos y nematodos fitopatógenos asociados al sistema radical en uva de mesa en la III Región de Chile. Aconex (Chile) 103:5-9.

Noe, J.P. 1985. Analysis and interpretation of data from nematological experiments. In: K. Barker, 
C. Carter, and J. Sasser, (eds.). An advanced treatise on Meloidogyne. Volume II, Methodology. North Carolina State University Graphics, Raleigh, North Carolina. 223 pp.

Oostenbrink, M. 1966. Major characteristics of the relation between nematodes and plants. In: $\mathrm{H}$. Veenman and Zonen (eds.). Medederlingen van de Landbouwhogeschool, Wageningen (Netherlands) $66.48 \mathrm{pp}$.

Osorio, A., F. Tapia, and R. Salinas. 1995. Suelos y climas del valle del Huasco y sus alternativas de cultivo. INIA-Intihuasi. La Serena, Chile. Cartilla Divulgativa $\mathrm{N}^{\circ} 1.12 \mathrm{pp}$.

Pacajes, G., J. Franco, R. Estrella, and G. Main. 2002. Efecto de diferentes cultivos y prácticas culturales sobre la multiplicación del nematodo quiste de la papa (Globodera spp.) en Bolivia. Revista Latinoamericana de la Papa 13:52-65.

Peoples, M., D. Herrdge, and J. Ladha. 1995. Biological nitrogen fixation: An efficient source of nitrogen for sustainable agricultural production? American Journal of Alternative Agriculture 10:88-96.

Pinkerton, J.N., T.A. Forge, K.L. Ivors, and R.E. Ingham. 1999. Plant-parasitic nematodes associated with grapevines, Vitis vinifera, in Oregon vineyards. Supplement to the Journal of Nematology 31:624-634.

Rahman, L., K. Chan, and D. Heenan. 2007. Impact of tillage, stubble management and crop rotation on nematode populations in a long-term field experiment. Soil and Tillage Research 95:110-119.

Rivera, L., and E. Aballay. 2008. Nematicide effect of various organic soil amendments on Meloidogyne ethiopica whitehead, 1968, on potted vine plants. Chilean Journal of Agricultural Research 68:290-296.
Rodriguez-Kábana, R., G. Morgan-Jones, and I. Chet. 1987. Biological control of nematodes: Soil amendments and microbial antagonists. Plant and Soil 100:237-247.

Sasser, J.N., and D.W. Freckman. 1987. A world perspective on Nematology: the role of the society. p. 7-14. In: J.A. Veech and D.W. Dickson (eds.). Vistas on Nematology. Society of Nematologists, Hyattsville, Maryland.

Scholte, K., and M. Lootsma. 1998. Effect of farm manure and green manure crops on populations of mycophagous soil fauna and Rhizoctonia stem canker of potato. Pedobiologia 42:223-231.

Sellés, G., R. Ferreyra, M. Pinto, and R. Ruiz. 2012. Portainjertos en uva de mesa: experiencias en el Valle de Aconcagua. Boletín INIA No 251. Santiago, Chile. 110 pp.

Smiley, R. 2005._Plant-parasitic nematodes affecting wheat yield in the Pacific Northwest. Oregon State University, extension publication. EM 8887.4 pp.

Southey, J.F. 1986. Laboratory methods for work with plant and soil nematodes. Ministry of Agriculture, Fisheries and Food, Reference Book 402. Her Majesty`s Stationary Office. London, U.K. 202 pp.

Tsay, T.T., S.T. Wu, and Y.Y. Lin. 2004. Evaluation of Asteraceae plants for control of Meloidogyne incognita. Journal of Nematology 36:36-41.

Valenzuela, A., and E. Aballay. 1996. Evaluación del control químico de Xiphinema index en vides. Nematropica 26:177-179.

Villate, L., E. Morin, G. Demangeat, M. Van Helden, and D. Esmenjaud. 2012. Control of Xiphinema index populations by fallow plants under greenhouse and field conditions. Phytopathology 102:627-634. 
